\title{
MENELUSURI JEJAK HOAKS DARI KACAMATA BAHASA: BAGAIMANA MENDETEKSI BERITA PALSU SEDINI MUNGKIN ${ }^{1}$
}

\author{
Eric Kunto Aribowo \\ PBSD, FKIP, Universitas Widya Dharma Klaten \\ erickunto@unwidha.ac.id
}

\begin{abstract}
ABSTRAK
Digitalisasi komunikasi mendorong setiap orang untuk mampu memproduksi dan mencerna informasi maupun berita melalui media digital. Belakangan, masyarakat dan pemerintah Indonesia dibuat jengah dengan fenomena penyebaran berita fitnah, hasut, dan hoaks yang semakin marak terjadi. Dengan menggunakan sumber data berupa pranala https://www.turnbackhoax.id dan https://www.hoaxbuster.id serta forum virtual anti-hoaks di Facebook dilakukan identifikasi karakteristik berita hoaks menggunakan bingkai kebahasaan. Penggunaan judul yang provokatif, pungtuasi yang berlebihan, kata-kata berunsur imperatif, bahasa yang nirbaku, pemberitaan dengan bahasa yang vulgar dan sarkastis merupakan fenomena yang lazim ditemukan di media sosial dan aplikasi pesan instan. Peningkatan literasi media menjadi hal yang mutlak dilakukan agar masyarakat mampu mengenali dan memahami konten yang disampaikan media sehingga mampu menentukan apakah sebuah informasi tersebut merupakan hoaks atau bukan. Karena itu, melek media digital, salah satu dari apa yang disebut sebagai bagian $21^{\text {st }}$ century skills, menjadi penting untuk disebarkan.
\end{abstract}

Kata kunci: berita bohong, fake news, clicking monkey, media digital, kode etikjurnalistik

\section{PENDAHULUAN}

Pesatnya perkembangan teknologi informasi dan komunikasi memiliki konsekuensi yang berdampak pada perubahan pola produksi dan konsumsi informasi yang dilakukan oleh khalayak umum². Akhir-akhir ini, tren yang terjadi ialah masyarakat mulai beralih dari media konvensional (media cetak dan televisi) ke media digital dalam rangka mendapatkan informasi aktual dan faktual. Informasi yang dipublikasikan melalui media digital cenderung dipilih karena memang memiliki kecepatan akses yang lebih tinggi apabila dibandingkan dengan media konvensional. Sayangnya, sebagai akibat kecepatan akses tersebut, informasi yang beredar acap kali tanpa melalui proses penyuntingan dan verifikasi kebenaran yang jelas. Akibatnya, masyarakat merasa linglung 'kebingungan' ketika berita fakta dan berita bohong berseliweran silih berganti dengan begitu cepatnya. Gejala yang merujuk pada fenomena yang dikenal dengan istilah kejutan budaya (culture shock). Kejutan ini ditandai dengan hadirnya kegelisahan yang dirasakan seseorang atau masyarakat ketika beralih ke lingkungan kultur yang berbeda (dalam konteks ini era digital) serta munculnya disorientasi personal terhadap pengalaman baru dalam memanfaatkan teknologi. Masyarakat yang biasanya disuguhi informasi dari sumber-sumber media konvensional -yang

\footnotetext{
${ }^{1}$ Aribowo, E. K. (2017) "Menelusuri Jejak Hoaks dari Kacamata Bahasa: Bagaimana Mendeteksi Berita Palsu Sedini Mungkin," in Retnatiti, S., Rosyidah, dan Bukhori, H. A. (ed.) Literasi dalam Pembelajaran Bahasa. Malang: Universitas Negeri Malang, hal. $78-87$.

${ }^{2}$ komposisi pengguna internet di Indonesia melonjak drastis dari 88 juta pengguna di tahun 2014 menjadi 132,7 juta (atau sekitar 52\% dari jumlah penduduk) pengguna internet di tahun 2016 (APJII, 2016)
} 
telah melalui proses editorial yang ketat- menjumpai permasalahan baru ketika setiap orang dapat memproduksi informasi dan berita yang kemudian disebarluaskan melalui media digital. Kebenaran dan kebohongan bercampur menjadi sehingga suatu informasi akan tampak samar, abu-abu, dan bias.

Eksodus penikmat berita ke arah media digital pun dapat mendefinisikan ulang pengertian media arus utama yang selama ini didominasi oleh media konvensioanal. Karena pada kenyataannya, media digital kini menjadi kiblat baru bagi para pencari informasi. Terjadinya pergeseran ini dibuktikan dengan makin maraknya saluran/acara televisi yang mengadopsi berita dari informasi yang dipublikasikan melalui media digital. Tidak jarang, acara seperti On The Spot ${ }^{3}$ mulai mewarnai tiap-tiap saluran televisi. Bahkan, beberapa saluran televisi yang acaranya didominasi oleh acara berita, menampilkan kejadian-kejadian terkini yang saat ini menjadi viral atau trending topic di media sosial seperti Twitter, YouTube, maupun Facebook. Tak ayal, peluang ini dimanfaatkan oleh orang-orang yang tidak bertanggung jawab untuk menyebarkan berita bohong. Media sosial menjadi pasar yang menjanjikan bagi sirkulasi hoaks (Sunudyantoro et al., 2017; Widjanarko, 2017) untuk mengganggu ketenteraman masyarakat di segala lapisan, tidak mengenal usia, profesi, bahkan tingkat pendidikan sekali pun.

Sebagai bukti, hoaks telah memicu pertikaian di masyarakat, misalnya pada Juli tahun lalu terjadi pembakaran vihara dan kelenteng di Tanjung Balai, Sumatera Utara (Tempo, 2017b). Masyarakat dengan cepat berkumpul dan marah akibat hasutan melalui media sosial. Peristiwa kedua terjadi di Depok, Jawa Barat pertengahan Desember lalu. Dua orang tewas dan satu kritis gara-gara tawuran yang juga disulut oleh kabar bohong (Tempo, 2017a).

Menurut survei yang dilakukan oleh Mastel, responden yang terdiri dari $26 \%$ lulusan SMA/SMK, $46,50 \%$ S1, dan $14,60 \%$ S2 mengaku $54 \%$ ragu-ragu, $28 \%$ mampu mengenali hoaks, dan $18 \%$ tidak mengetahui apa itu hoaks (Mastel, 2017). Perilaku masyarakat ini mengisyaratkan bahwa di Indonesia (dimungkinkan pula terjadi di negara-negara berkembang lainnya) tidak ada hubungan yang signifikan antara tingkat pendidikan dan kemampuan analisis hoaks. Dengan kata lain, hubungan antara tingkat pendidikan dan tingkat literasi tidak berbanding lurus. Seseorang yang berpendidikan doktor atau bahkan profesor sekalipun belum tentu menjamin dapat mendeteksi atau memilah berita fakta dan berita bohong dengan mudah. Inilah sebabnya, mendeteksi hoaks bukanlah pekerjaan yang mudah karena yang sering terjadi, fakta dan kepalsuan dicampur-adukkan untuk mengecoh pembaca sehingga terbangun kesan sebagai sebuah "temuan atau kebenaran yang baru terkuak" (Priyambodo, 2013).

Kemajuan teknologi informasi dan komunikasi juga mempercepat hoaks tersebar luas. Tidak mengherankan media sosial menjadi sasaran utama karena menjadi aplikasi yang paling sering diakses oleh pengguna internet ${ }^{4}$. Masyarakat disuguhi oleh banyaknya berita jadi-jadian yang mondar-mandir di lini masa pada akun media sosial pribadi masing-masing. Karena judul yang sering kali provokatif, bombastis, dan heboh, akibatnya pengguna terpancing dan dengan begitu mudahnya ikut menyebarluaskan dengan membagikan (share) dan menyiarkan (broadcast) ke akun-akun lain yang dikenalnya. Aktivitas ini bahkan kerap kali tidak didahului dengan klarifikasi atau pengecekan terhadap kebenaran informasi tersebut,

\footnotetext{
${ }^{3}$ sebuah acara yang menayangkan 7 informasi unik yang belum banyak terekspos oleh media lain. Tayangannya diadopsi dari video-video yang diunggah di YouTube

${ }^{4}$ kenyataan ini disebabkan karena media sosial (Instagram, Facebook, Path) dan aplikasi persesanan (Line, Whatsapp, $B B M$ ) merupakan aplikasi yang paling sering digunakan oleh masyarakat selain peta, $e$-commerce, dan pemesanan tiket (Mastel \& AJPII, 2O16)
} 
fenomena yang disebut Priyambodo (2013) dengan istilah clicking monkey5. Inilah bukti kejutan budaya yang terjadi di sekitar kita.

Usaha meredam penyebaran hoaks sebenarnya sudah mulai dilakukan, mulai dari verifikasi media dan pemblokiran situs oleh Kemenkominfo (Perkasa, 2017) dan verifikasi pers (Gual, 2017), lahirnya komunitas anti hoaks di berbagai kota besar (Nugraheny, 2017), dan forum-forum diskusi, baik bersifat virtual atau melalui tatap muka. Tampaknya, satu-satunya usaha yang mujarab untuk menanggulangi penyebaran hoaks di Indonesia ialah melalui edukasi peningkatan literasi sebagaimana dikatakan Rudiantara, Menkominfo (Librianty, 2017; Perkasa, 2017). Kecerdasan dalam mencerna dan memproduksi informasi menjadi hal pokok yang tidak dapat ditampik di era digital ini. Inilah sebabnya, literasi digital menjadi salah satu bagian dari kecakapan abad ke-21 (21st century skills) yang wajib dimiliki penduduk dunia (Widjanarko, 2017) yang selayaknya dapat mulai diimplementasikan ke dalam kurikulum sekolah-sekolah sebagaimana yang terjadi di negara-negara maju (Cheung, 2016; Leung \& Ruan, 2012; Li \& Tsao, 2016).

Salah satu bentuk peningkatan literasi dapat diraih dengan edukasi yang berkelanjutan kepada khalayak. Dengan meningkatnya daya kritis dan analisis yang semakin tajam diharapkan dapat menjadi bekal masyarakat dalam menghadapi masifnya informasi yang beredar. Dalam konteks ini, analisis bahasawi dapat berkontribusi dalam mendeteksi berita bohong, selain analisis yang bersifat keteknologian. Judul, teras, dan bagian isi berita yang diproduksi dengan sarana bahasa faktanya dapat digunakan sebagai parameter pendeteksi gejala sebuah berita hoaks. Tulisan singkat ini memaparkan fitur-fitur linguistis yang muncul dengan frekuensi yang tinggi dalam beberapa berita hoaks, mulai dari tanda baca, kata, hingga narasi yang digunakan dalam sebuah berita bohong.

Berita bohong atau yang lebih dikenal dengan sebutan hoaks (hoax; hocus pocus) didefinisikan sebagai kebohongan yang dibuat secara sengaja untuk menyamarkan kebenaran yang ada (Macdougall, 1935). Dalam Merriam Webster hoaks dimaknai sebagai upaya mengelabui objek untuk memercayai atau menerima sesuatu yang keliru dan tidak masuk akal (Media Indonesia, 2017). Dalam KBBI daring, hoaks diartikan: (1) tidak benar, bohong (tentang berita, pesan, dan sebagainya); (2) berita bohong (Wahyu, 2017). Dalam perkembangannya, hoaks dapat diartikan sebagai kabar palsu yang sengaja disebar untuk mencari kehebohan publik.

Meskipun menurut persentase isu politik menjadi topik hangat terkait hoaks ${ }^{6}$ (Mastel, 2017), namun isu-isu lain seperti sara, makanan dan minuman, kesehatan, berita duka juga menjadi sasaran pemberitaan berita bohong. Pemberitaan persilangan sapi dan babi, minuman White Koffie yang mengandung babi, biskuit mudah terbakar karena mengandung lilin, Paus Yohanes II masuk Islam, vaksin kanker serviks menyebabkan menopause dini, serbuan 10 juta pekerja asal China, dan pemberitaan kematian B.J. Habibie pernah menjadi berita yang naik daun di media-media sosial dan aplikasi perpesanan instan.

\section{METODE}

Sumber data yang dimanfaatkan dan disajikan berkenaan dengan berita hoaks diambil dari pranala forum anti-hoaks www.turnbackhoax.id dan www.hoaxbuster.id; forum diskusi virtual dari laman www.facebook.com/IndoHoaxBuster; www.facebook.com/groups/FAFHH; serta beberapa hasil skrinsyut koleksi pribadi penulis. Dipilihnya sumber ini karen berita-berita yang dimuat telah diverivikasi dan diuji

\footnotetext{
${ }^{5}$ para pengguna internet yang membagikan informasi (melakukan click) ke siapa pun tanpa klarifikasi terlebih dahulu ${ }^{6}$ isu politik menjadi topik berita yang paling banyak dipalsukan yang tidak hanya terjadi di dalam negeri, namum di luar negeri pula. Hoaks jenis politik mulai banyak bermunculan sejak bergulirnya Pilpres 9 Juli 2014, kasus penistaan agama, Pilkada Serentak 15 Pebruari 2017, dan Pilgub Jakarta Putaran Dua 19 April 2017
} 
benar tidaknya berita tersebut dengan sumber berita lain yang lebih terpercaya sehingga telah diidentifikasi sebagai hoaks. Berita yang telah diskrinsut tersebut kemudian didokumentasikan, diklasifikasikan, serta dianalisis berdasarkan kesamaan dalam unsur-unsur kebahasaannya, mulai dari tanda baca, kata, hingga teks narasi memanfaatkan teknik baca markah ${ }^{7}$ sebagaimana dikemukakan oleh Sudaryanto (2016).

Judul, teras, dan isi berita menjadi bagian-bagian yang pokok yang menjadi poin perhatian, terutama judul karena menurut fenomena yang marak terjadi bahwa silent majority ${ }^{8}$ seringkali menyebarkan sebuah berita disebabkan oleh terpancing judul tanpa membuka dan membaca isi berita secara keseluruhan. Akhirnya, ciri-ciri atau karakteristik bahasa hoaks dapat dipetakan sebagai piranti untuk mengecek hoaks atau berita fakta.

\section{HASIL DAN PEMBAHASAN}

Dari hasil temuan, hoaks paling banyak beredar di media sosial Facebook ${ }^{9}$. Penyebaran berita sering kali dilakukan oleh akun yang tidak jelas pemiliknya. Hal ini dapat diketahui dari nama akun yang bersangkutan yang biasanya tidak menggunakan nama asli; menggunakan nama alias yang sering kali lebih panjang. Kemudahan pembuatan akun baru dan tidak adanya verifikasi data diri oleh penyedia layanan menjadi alasan munculnya akun-akun palsu yang dikelola oleh orang-orang yang tidak bertanggung jawab.

Pelaku penyebaran hoaks sebenarnya dapat dipilah menjadi dua: (1) pelaku yang dengan sengaja ${ }^{10}$ menyebar hoaks; (2) pelaku yang tidak sengaja menyebar hoaks. Jumlah pelaku yang tidak sengaja menyebar hoaks dapat dikurangi dengan jalan meningkatkan kemampuan literasi. Dengan demikian, dapat beralih menjadi pengguna yang cerdas (bahkan mampu mengklarifikasi apabila muncul berita hoaks) sehingga berita bohong dapat surut dengan sendirinya.

Berikut ini dipaparkan hasil temuan yang dapat dimanfaatkan sebagai pendeteksi hoaks, khususnya melalui piranti bahasa.

\subsection{Judul yang Provokatif}

Judul seyogyanya merupakan intisari berita sehingga isi berita dapat diketahui secara singkat melalui pembacaan judul. Inilah sebabnya, judul dibuat semenarik mungkin demi menarik animo pembaca. Judul yang baik tidak mengarah pada pembiasan berita, mengandung provokatif, dan berpotensi menjadi masalah. Kebanyakan yang terjadi pada hoaks, judul dibuat agar menarik mata pembaca 'eye-catching' sehingga kadang ditambahkan foto sebagai ilustrasi untuk lebih meyakinkan pembaca". Dengan cara ini, opini atau pandangan pembaca diarahkan agar segera menyimpulkan 'jump to conclution' tanpa harus membaca isi berita secara lengkap.

Judul-judul yang bersifat provokatif biasanya terkait isu yang sedang marak diperbincangkan.Juduljudul pancingan pada dasarnya kontras dengan judul-judul yang dimuat pada berita dari sumber yang

\footnotetext{
${ }^{7}$ dilakukan dengan jalan membaca pemarkah atau penanda dalam sebuah konstruksi bahasa

${ }^{8}$ klasifikasi pengguna hoaks yang secara tidak sengaja menyebarluaskan hoaks karena ketidaktahuan dan tidak melakukan pengecekan berita terlebih dahulu

${ }^{9}$ Sepanjang tahun 2016, sekitar 300 akun media sosial dan media online yang menyebarkan hoaks, provokasi, dan sara telah diblokir oleh Direktorat Reskrimsus Polda Metro Jaya (Media Indonesia, 2017)

${ }^{10}$ bahkan di beberapa situasi terkesan terkoordinasi dengan baik karena setiap ada seseorang yang mencoba memberikan klarifikasi akan diserang dengan akun-akun lain demi membiaskan klarifikasi tersebut

${ }^{11}$ pada beberapa kasus yang terjadi, foto lama atau foto pada kesempatan lain diklaim sebagai sebuah berita baru yang dibelokkan. Pada kasus lainnya, gambar atau foto direkayasa atau diedit sedemikian rupa agar mendukung opini yang dimuat, misalnya pada pemberitaan jembatan Cisomang beberapa waktu silam
} 
handal, misalnya Kompas, Koran Tempo, Republika, Media Indonesia. Judul-judul pada berita bohong dirangkai sedemikian rupa sehingga seolah-olah tampak sebagai sebuah kebenaran atau fakta yang baru terungkap. Tidak berimbang, partisan, dan mengandung unsur hasutan menjadi ciri-ciri judul yang provokatif.

\section{Narasi $1 \quad$ WAW HEBOH !!! BERITA PAGI INI : PERNYATAAN TERBARU PANGLIMA TNI: KAMI AKAN HABISI SEMUA PKI DI INDONESIA WALAU PRESIDEN JOKOWI MELARANG ,.. GATOT: TETAP SAYA LAKUKAN WALAU RESIKO DIPECAT !!! (Lampiran 1c)}

Narasi 2 Aneh, suara Anies-Sandi Tiba-Tiba Berkurang 70oo Padahal Data Sudah 100\% (Lampiran 1e)

Narasi 3 Anies : Ada Percobaan Pembunuhan Oleh Ahok Terhadap Saya Dalam Kasus Jatuhnya Lift (Lampiran ih)

Isu komunisme yang beberapa waktu lalu mengemuka menjadi topik pada Narasi 1. Judul tersebut diambil dari kutipan (yang seolah-olah berasal) dari pernyataan Panglima TNI. Pemberitaan semacam ini dimanfaatkan untuk memancing kemarahan para pendukung orang yang diberitakan dan lebih berorientasi kepada adu domba dan penghasutan. Dalam konteks ini, Panglima TNI diberitakan berani melanggar instruksi Presiden -yang sebenarnya tindakan yang mustahil terjadi.

Pada Narasi 2 dan 3 beredar tatkala berlangsungnya Pilkada Serentak. Pembuat berita menggunakan kata "aneh" untuk memancing ketertarikan pembaca terkait isu penghitungan hasil suara Pilkada. Kata "aneh" dapat digunakan untuk menyulut keraguan seseorang terhadap sebuah kondisi yang di luar kewajaran. Berita ini digunakan untuk mempengaruhi lawan politik beserta massa pendukungnya. Judul berita pada Narasi 3 bersifat provokatif dengan jalan melakukan fitnah atas perbuatan yang sebenarnya tidak dilakukan.

\subsection{Pungtuasi yang Berlebihan}

Pewarta berita yang baik tentu telah dibekali dengan ilmu-ilmu jurnalistik, bahasa, dan komunikasi yang matang. Pewarta profesional tentu saja memegang teguh prinsip-prinsip atau kode etik jurnalistik. Sebuah berita yang terpercaya tentu melalui proses suntingan terlebih dahulu sebelum dinyatakan layak terbit dan dipublikasikan sehingga keabsahan informasi terjaga, termasuk dalam kesalahan tata tulis.

Data-data yang ada menunjukkan bahwa hoaks ditandai dengan hadirnya pungtuasi atau tanda baca yang digunakan secara berlebihan, baik berupa tanda titik (.) maupun tanda seru (!) sebagaimana pada Narasi 4, 5, dan 6. Padahal, sebuah kalimat yang efektif hanya membutuhkan satu buah tanda baca, tergantung jenis kalimatnya. Tanda baca titik untuk kalimat pernyataan dan tanda seru untuk kalimat suruh atau larangan.

\footnotetext{
Narasi $4 \quad$ BERITA TERBARU...!!! PUKUL 08.3O KPK JEMPUT PAKSA ANIES BASWEDAN DI RUMAHNYA , KARENA TERSANDUNG KASUS KORUPSI DANA FRANKFURT BOOKFAIR (Lampiran 1a)

Narasi 5 BERITA TERHEBOH MALAM INI...!! Setya Novanto; Jika Ahok Gagal Jadi Gubernur Ahok Akan Kami Angkat Menjadi Ketua KPK...SHARE (Lampiran 1m)
} 
Narasi 6 Berita pagi hari ini yang menghebohkan dunia..!!! paus yohanes II, Atau yang Akrab Dipanggil Sri Paus,Pimpinan Umat Katholik Sedunia Masuk ISLAM,Sekitar jam 10 Tadi Pagi Dimasjidil Harham..TOLONG DI SHARE !!!! (Lampiran in)

Pada beberapa contoh yang ditampilkan di atas dapat diamati hadirnya tanda baca titik dan tanda seru yang berjumlah lebih dari satu. Tanda seru secara serempak digunakan untuk mengakhiri kalimat pembuka pada ketiga data, baik dengan dua atau tiga buah tanda seru. Tanda seru tersebut bahkan sebelumnya diawali oleh dua atau tiga tanda baca titik. Kasus semacam ini melanggar kaidah Pedoman Umum Ejaan Bahasa Indonesia.

\subsection{Kata yang Berunsur Imperatif}

Berita bohong dapat diindikasikan dari munculnya kata-kata yang berunsur imperatif, baik berupa suruhan maupun larangan. Kata-kata kerja imperatif yang acap kali muncul misalnya "share", "bagikan", "like", "sebarkan"; dan kata yang digunakan untuk menyatakan 'ketakjuban' seperti "aneh", "heboh", "waw", "astaga" lazim digunakan pada berita palsu. Sebuah berita yang baik tentunya tidak diukur dari berapa jumlah "like" atau komentar yang didapatkan.

Kata-kata yang berwujud perintah sebagaimana terdapat pada contoh Narasi 7 -10. Kerap kali kalimat yang mengandung kata perintah tidak diakhiri oleh tanda seru, tetapi diawali oleh kata bantu perintah. Kata-kata yang diawali dengan menggunakan kata tolong, silakan, mohon juga menandai kata-kata yang bermakna perintah, suruhan, atau ajakan. Pada contoh-contoh yang disajikan di bawah ini, tampak digunakannya kata "komen", "tolong sebarkan", "sebarkan", dan "silakan berbagi" yang tujuannya untuk menyuruh.

\footnotetext{
Narasi $7 \quad$ Bapak meskin ini diceburin ke got td pagi hanya karena mencuri satu buah apel utk anaknya yg sakit kelaparan.. Yg melihat komen aamiin semoga rezeki bapak ini melimpah ruah aamiiin.. (Lampiran $1 b$ )

Narasi 8 Kemarin di Thailand ditemukan 1 buah Mobil van berisi hampir 100 tubuh anak2 dlm keadaan meninggal dan dibungkus plastik. Semua tubuh dalam keadaan TANPA ORGAN TUBUH! Mulai saat ini berhati-hatilah dgn anak anda kemanapun dia pergi DAMPINGILAH! Baik sekolah dan bermain, sindikat ini sdh menyebar ke pelosok pelosok di negara manapun. Tolong sebarkan ini. (Lampiran if)

Narasi 9 Yg belum punya....suru di sebarkan...kita sebagai orangtua. Waspda .(Lampiran ii)

Narasi $10 \quad$ Peringatan urgent! Hati-hati untuk tidak menggunakan parasetamol yang datang ditulis P / 5oo. Ini adalah parasetamol baru, sangat putih dan mengkilap, mengandung "Machupo" virus, dianggap salah satu virus yang paling berbahaya di dunia. Dan dengan tingkat kematian yang tinggi. Silakan berbagi pesan ini, untuk semua orang dari keluarga. Dan menyelamatkan hidup dari mereka saya sudah melakukan bagian saya, sekarang giliran Anda (Lampiran ık)
}

Ada beberapa tipe dalam penggunaan kata berunsur imperatif apabila ditinjau dari lokasi penempatannya. Tipe pertama, kata imperatif ditempatkan di awal narasi. Tipe kedua kata imperatif berada di bagian tengah narasi dan tipe ketiga diletakkan di bagian akhir narasi. Pada tipe pertama, bentuk imperatif mengawali kalimat dengan tujuan untuk menarik perhatian pembaca. Pada tipe ketiga, narasi diawali 
dengan sebuah cerita singkat tentang sebuah kejadian yang pernah atau sedang dialami. Dengan cerita tersebut pembuat hoaks seakan-akan memberikan nasihat kepada pembaca agar tidak mengalami kejadian serupa. Berita tersebut padahal tidak benar-benar terjadi. Tujuan sebenarnya adalah untuk membuat masyarakat merasa cemas dan kuatir. Tipe ini juga beberapa kali muncul untuk menyeru melakukan pemboikotan terhadap sebuah produk tertentu ${ }^{12}$.

Kata-kata yang merujuk pada makna 'kekaguman’ seperti kata “waw” yang termuat pada Narasi 11.

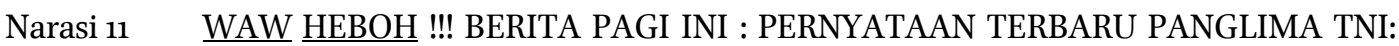
KAMI AKAN HABISI SEMUA PKI DI INDONESIA WALAU PRESIDEN JOKOWI MELARANG ,.. GATOT: TETAP SAYA LAKUKAN WALAU RESIKO DIPECAT !!! (Lampiran 1c)

\subsection{Bahasa yang Nirbaku}

Karena hoaks pada dasarnya bukan diproduksi oleh orang yang berkompetensi di bidang jurnalistik, bahasa yang digunakan pun jauh dari kaidah-kaidah kebahasaan yang berlaku. Bahasa yang digunakan pada umumnya menggunakan kata-kata yang tidak baku, percampuran huruf kapital dan huruf kecil pada beberapa kalimat, penyingkatan beberapa kata, serta susunan kalimat yang tidak gramatikal.

Narasi 12 Kerjasama dengan Tiongkok membuat rel kereta api cepat di Uni Emirat Arab dapat hadiah jutaan pil Ekstasi..... (Lampiran 1)

Narasi 13 BERITA TERHEBOH MALAM INI...!! Setya Novanto; Jika Ahok Gagal Jadi Gubernur Ahok Akan Kami Angkat Menjadi Ketua KPK..SHARE (Lampiran 1m)

Narasi 12 dan 13 jika ditinjau dari stuktur kalimatnya, tidak tergolong ke dalam stuktur kalimat bahasa Indonesia. Subjek yang menjadi salah satu inti kalimat, tidak ditemukan pada Narasi 12. Salah satu kalimat pada Narasi 13 ialah bertipe kalimat majemuk bertingkat hubungan syarat yang ditandai dengan hadirnya kata penghubung "jika". Klausa inti pada kalimat itu adalah "Ahok Akan Kami Angkat menjadi Ketua KPK”. Apabila berita tersebut benar dan ingin dijadikan sebuah judul, maka pilihan yang lebih tepat ialah "Jika Gagal Jadi Gubernur, Ahok Akan Kami Angkat menjadi Ketua KPK" dan "Kerja Sama (Indonesia dengan) Tiongkok dalam Pembuatan Rel Kereta Api di Uni Emirat Arab Berhadiah Jutaan Pil Ekstasi”.

Percampuran huruf kapital dan huruf kecil pada beberapa kalimat dapat diamati pada Narasi 13. Kalimat yang ditulis menggunakan huruf kapital tampak pada kalimat pertama dan ketiga (terakhir), sedangkan penulisan huruf kecil terjadi pada kalimat kedua. Dengan kata lain, apabila dilihat dari tata bahasanya, bahasa hoaks akan terdengar (atau terbaca) aneh dengan struktur kata yang tidak lazim serta kalimat yang tidak mudah dipahami.

\subsection{Bahasa yang Mengandung Sarkasme}

Penggunaan kata-kata pedas untuk menyakiti orang lain, cemooh atau ejekan kasar juga menjadi variasi ungkapan yang sering dimuat pada berita hoaks. Bahasa-bahasa sarkasme atau yang lebih terkenal dengan "hate speech" biasanya diusung oleh partisan-partisan yang fanatik terhadap golongan tertentu.

\footnotetext{
${ }^{12}$ beberapa produk yang pernah menjadi korban hoaks seperti: Sari Roti, Aqua, White Koffie, minuman berenergi
} 
Tujuan pemberitaan hoaks model ini harapannya dapat menjatuhkan pihak lawan, khususnya terkait isuisu politik.

Narasi 14 Pegawai dilingkungan istana skr sdh mulai resah, krn sholat di masjid Baiturahim istana selain jum'atan sdh tdk boleh ada yg sholat disitu, tdk boleh ada suara adzan lagi kalau masuk waktu sholat, ini benar2 sdh kelewatan komunis biadab.! (Lampiran 1d)

Narasi 15 Raja Salman Yang Santun Serta Tuan Rumah Yang Bodoh (Lampiran 1g)

Kata biadab pada Narasi 14 memiliki makna 'tidak tahu adat (sopan santun); kejam'. Kata "biadab” dalam konteks ini digunakan untuk memaki atau mengumpat. Kasus yang sama terjadi pada Narasi $\mathbf{1 5}$. Pembuat berita menggunakan frasa "tuan rumah yang bodoh" untuk merujuk pada Presiden RI, Joko Widodo. Kata "bodoh" yang digunakan untuk menyifati tuan rumah merupakan ejekan kasar yang dialamatkan kepada seorang presiden. Kata-kata yang berasosiasi makna negatif salah satu fungsinya memang dimanfaatkan untuk melampiaskan rasa kemarahan atau kekecewaan seseorang.

Narasi 16 LIHATLAH.. BEGINI YG NAMANYA PELINDUNG RAKYAT.. REZIM BINATANG (Lampiran $\mathrm{j}$ )

Yang dimaksud rezim pada Narasi 16 ialah para anggota perwakilan rakyat. Pemerintah memang beberapa kali menjadi korban hoaks, khususnya dengan pemberitaan yang bernuansa hasutan. Terkait hal ini, Rudiantara (Rakyat Merdeka, 2017) menyebutkan bahwa "pemerintah sebenarnya bukan anti-kritik. Akan tetapi, jika kritik mengandung provokasi, propaganda, dan agitasi itu tidak dibenarkan."

Sebagaimana disebutkan dalam Surat Edaran Kapolri Nomor SE/06/X/2015, segala unggahan di media sosial yang bertujuan untuk menghasut dan menyulut kebencian terhadap individu dan atau kelompok masyarakat dalam berbagai komunitas yang berkaitan isu-isu suku, agama, aliran keagamaan, keyakinan atau kepercayaan, ras, antargolongan, warna kulit, etnis, gender, kaum difabel, dan orientasi seksual termasuk tindakan pidana (Kuwadi, 2015).

\section{PENUTUP}

Tanda-tanda kebahasaan yang telah dikemukakan sebelumnya dapat dimanfaatkan sebagai parameter untuk mendeteksi sebuah informasi masuk ke dalam berita fakta atau berita bohong. Akumulasi unsur-unsur tersebut di dalam sebuah berita mengindikasikan semakin besar berita tersebut mengarah kepada hoaks. Meskipun perlu dilakukan penelitian yang lebih seksama dengan menggunakan data yang lebih besar lagi, namun setidaknya paparan singkat ini dapat digunakan sebagai daftar pengecekan validitas sebuah berita.

Oleh karena itu, literasi media digital menjadi hal yang penting untuk digalakkan. Pengingkatan literasi media digital sudah selayaknya menjadi salah satu agenda penting dalam pembangunan manusia Indonesia. Tujuannya agar masyarakat dapat lebih bijaksana dalam mengkonsumsi dan memproduksi informasi di dunia digital. Ketika tingkat literasi meningkat, niscaya tercipta masyarakat yang lebih beradab, santun, dan bermanfaat. 


\section{DAFTAR RUJUKAN}

APJII. (2016). Infografis Penetrasi \& Perilaku Pengguna Internet Indonesia: Survey 2016. Jakarta.

Cheung, C.-K. (2016). Media Literacy Education in China. Singapore: Springer.

Gual, M. (2017). LBH Pers: Barcode Media Tak Efektif Tangkal Hoax. Diakses 25 Pebruari 2017, dari http://www.cnnindonesia.com/nasional/20170209163332-20-192399/lbh-pers-barcode-media-takefektif-tangkal-hoax

Kuwadi, F. J. (2015). Bermacam Hal yang Perlu Diketahui soal Edaran Kapolri tentang "Hate Speech." $\begin{array}{lllll}\text { Kompas.com. } & \text { Diakses } & 4 & \text { April } & \text { 2017, }\end{array}$ http://nasional.kompas.com/read/2015/10/30/o6o6ooo1/Bermacam.Hal.yang.Perlu.Diketahui.soal.Ed aran.Kapolri.tentang.Hate.Speech.

Leung, C. B., \& Ruan, J. (Eds.). (2012). Perspectives on Teaching and Learning Chinese Literacy in China. Dordrecht: Springer.

Li, C. W.-C., \& Tsao, J. H. (2016). The Routledge Course in Chinese Media Literacy. Devon, United Kingdom: Routledge.

Librianty, A. (2017). Peningkatan Literasi Masyarakat Dinilai Bisa Atasi Wabah Hoax - Tekno Liputan6.com. Diakses 25 Pebruari 2017, dari http://tekno.liputan6.com/read/285479o/peningkatan-literasimasyarakat-dinilai-bisa-atasi-wabah-hoax

Macdougall, C. D. (1935). Newspaper Hoaxes. Journalism \& Mass Communication Quarterly, 12(2), 166-177.

Mastel. (2017). Hasil Survey Mastel tentang Wabah Hoax Nasional. Diakses 4 April 2017, dari http://mastel.id/infografis-hasil-survey-mastel-tentang-wabah-hoax-nasional/

Mastel \& AJPII. (2016). Konklusi Survey Ekosistem DNA (Device, Network \& Apps). Jakarta.

Media Indonesia. (2017). Pak Menteri pun Korban Berita Bohong. Media Indonesia, 6.

Nugraheny, D. E. (2017). Gerakan Anti-hoax Dideklarasikan. Republika, 2.

Perkasa, A. (2017). Rudiantara Akui Pemblokiran Situs Hoax Tak Efektif. Diakses 25 Pebruari 2017, dari http://www.cnnindonesia.com/teknologi/20170202112030-185-190784/rudiantara-akui-pemblokiransitus-hoax-tak-efektif

Priyambodo, D. (2013). The Clicking Monkeys. Diakses 25 Pebruari 2017, dari https://www.tempo.co/read/kolom/2013/11/15/9oo/the-clicking-monkeys

Rakyat Merdeka. (2017). Kritik Bukan Hoax. Rakyat Merdeka, 1.

Sudaryanto. (2016). Metode dan Aneka Teknik Analisis Bahasa: Pengantar Penelitian Wahana Kebudayaan secara Linguistis (Edisi Kedua). Yogyakarta: Sanata Dharma University Press.

Sunudyantoro, Faiz, A., Alvionita, S., Elfaruqi, A., Maharani, S., Rudiana, P. A., \& Pahlevi, A. (2017). Kicau Kacau di Media Sosial. Majalah Tempo 8Januari, 29-33.

Tempo. (2017a). Berita Palsu Naik Pamor. Majalah Tempo 8Januari, 10.

Tempo. (2017b). Kabar Sesat di Atmosfer Kita. Majalah Tempo 8Januari, 25.

Wahyu, D. (2017). Kata "Hoaks" dan "Meme" Sudah Tercatat di Kamus Bahasa Indonesia. Kompas.com. Diakses April 2017, dari http://nasional.kompas.com/read/2017/o2/28/13203281/kata.hoaks.dan.meme.sudah.tercatat.di.kamu s.bahasa.indonesia

Widjanarko, P. (2017). Media Sosial yang Beradab. Majalah Tempo 8Januari, 40-41. 
Lampiran 1 Beberapa Contoh Berita Hoaks yang Beredar di Media Sosial, Aplikasi Pesan Instan, dan Pranala

See Translation

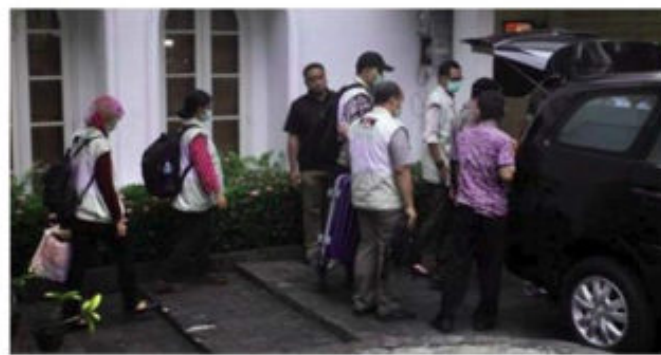

BERITA TERBARU...!!! PUKUL 08.30 KPK JEMPUT PAKSA ANIES BASWEDAN DI RUMAHNYA, KARENA TERSANDUNG KORUPSI DANA FRANKFURT BOOK.

cursaghourcogseor con

$36 \div ! n=04.18$

\section{뭉 $\leftrightarrow$, \\ 6. Asmaul Husna added a new photo. 1. Feb 12 at 14:33 8}

Bapak meskin ini diceburin ke got td pagi hanya karena mencuri satu buah apel utk anaknya yg sakit kelaparan.. Yg melihat komen aamiin semoga rezeki bapak in melimpah ruah aamiin.

\#bantu SebarKan agar bnyk mendoakan!!! with Umi Pipik Dian Irawati and Husnul Khatimah.

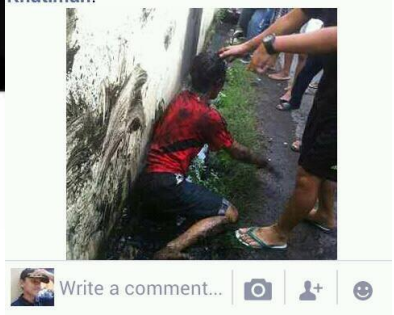

(a)

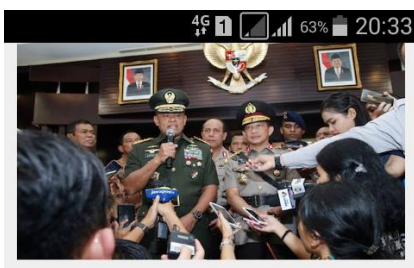

Home > TRENDING TOPIC

WAW HEBOH !!! BERITA PAGI INI : PERNYATAAN TERBARU PANGLIMA TNI: KAMI AKAN HABISI SEMUA PKI DI INDONESIA WALAU PRESIDEN JOKOWI MELARANG ,..GATOT: TETAP SAYA LAKUKAN WALAU RESIK.

(c)

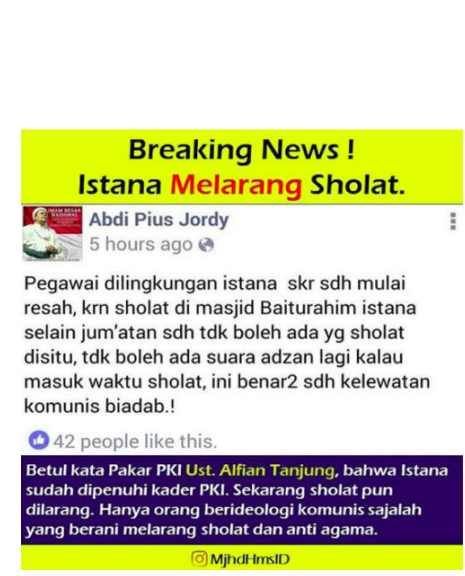

(d)

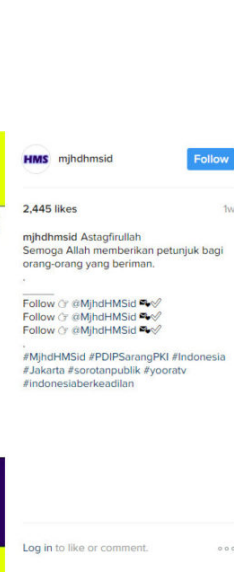

(6)

$\leftarrow$ Q Islamedia

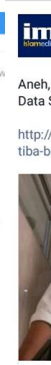
Aneh, Suara Anies-Sandi Tiba-Tiba Berkurang 7000
Padahal Data Sudah 100\%

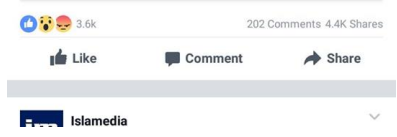

(e)

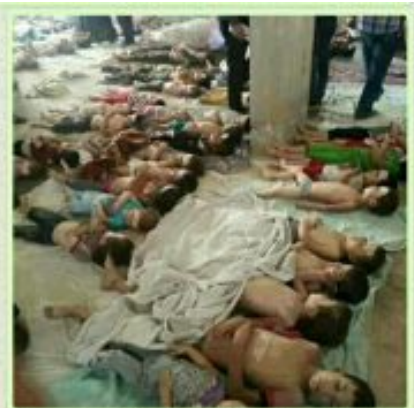

Kemarin di Thailand ditemukan 1 buah Mobil van berisi hampir 100 tubuh anak2 dlm keadaan mninggal dan dibungkus plastik. Semua tubuh dalam keadaan TANPA ORGAN TUBUH! Mulai saat ini berhati-hatilah dgn anak anda kemanapun dia pergi DAMPINGILAH! Baik sekolah dan bermain, sindikat ini sdh menyebar ke pelosok pelosok di cegara manapun. Tolong sebarkan ini.

(f)

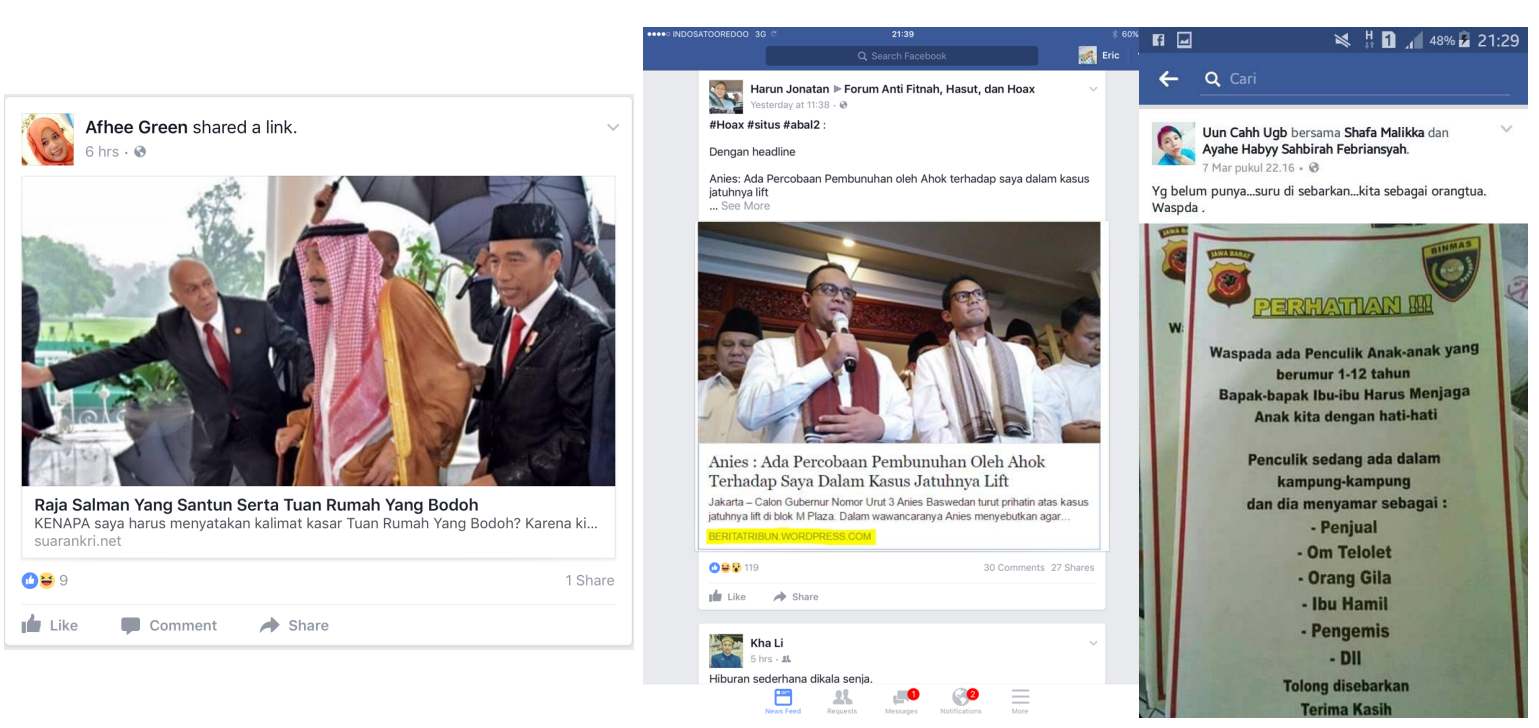


(g)

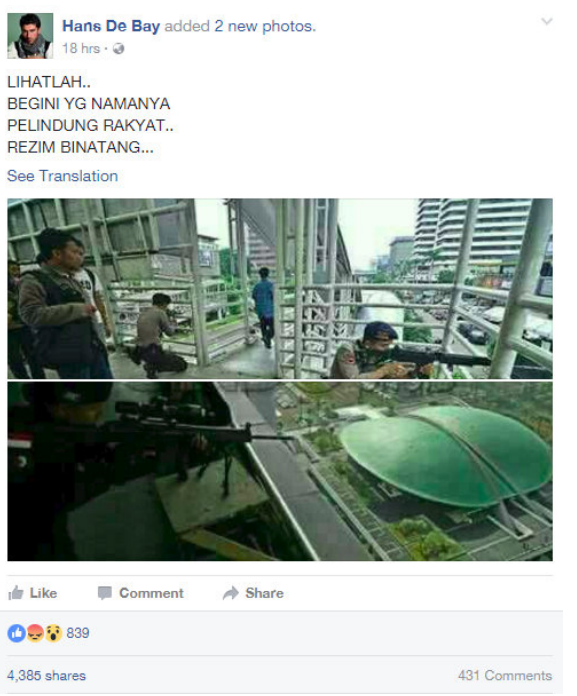

(j) (h)

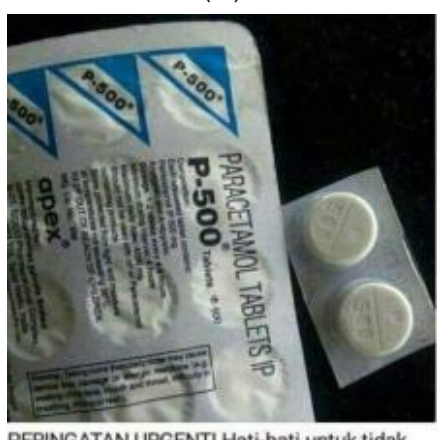

PERINGATAN URGENT! Hati-hati untuk tidak menggunakan parasetamol yang datang ditulis $\mathrm{P} / 500$, Ini adalah parasetamol baru, sangat putih dan mengkilap, mengandung "Machupo' virus, dianggap salah satu virus yang paling berbahaya di dunia. Dan dengan tingkat kematian yang tinggi. Silakan berbagi pesan ini, untuk semua orang dan keluarga.

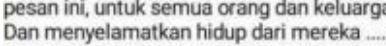
saya sudah melakukan bagian saya, sekarang giliran Anda

(k)

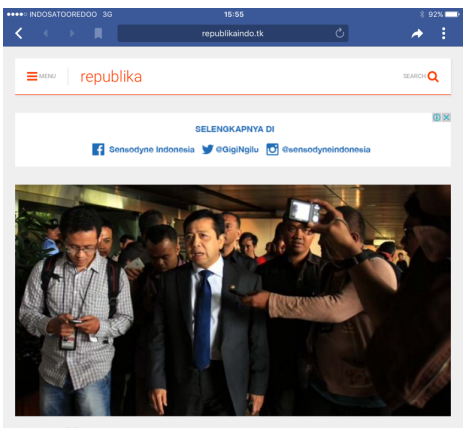

BERITA TERHEBOH MALAM INI...!! Setya Novanto; Jika Ahok Gagal Jadi Gubernur Ahok Akan Kami Angkat Menjadi Ketua KPK..SHARE

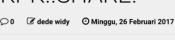

(i)

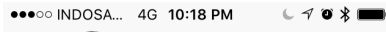
< 1 Daycare Primagama

Zunda Primagama

!! !! WARNING!! !!

Mohon ijin info Ikatan Dokter

Indonesia (IDI),

menginformasikan bahwa saat in

sedang ada wabah Pengerasan

Otak (Kanker Otak), Diabetes da

Pengerasan Sumsum Tulang

Belakang (Mematikan sumsum

tulang belakang).

Untuk itu, hindarilah minuman

sbb:

1. Extra Joss,

2. $\mathrm{M}-150$,

3. Kopi Susu Gelas (Granita),

4. Kiranti,

5. Krating Daeng,

6. Hemaviton,

7. Neo Hemaviton,

8. Marimas,

9. Seqar Sari shachet

$+$

(l)

$(\mathrm{m})$

(n)

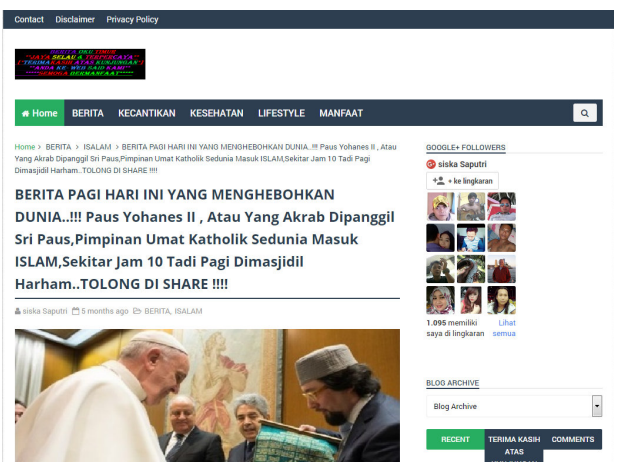

(o) 